\title{
ASSESSMENT OF SELECTED PARAMETERS OF SOWING QUALITY OF VISTULA PARSLEY SEEDS WITH A PRECISION SEED DRILL WITH A PNEUMATIC SEEDING SYSTEM
}

\author{
Szymon Ignaciuk ${ }^{\mathrm{a}}$, Janusz Zarajczyk $\mathrm{b}^{*}$ \\ a Department of Applied Mathematics and Computer Science, University of Life Sciences in Lublin, \\ e-mail: szymon.ignaciuk@up.lublin.pl, ORCID 0000-0001-8288-2833 \\ b Department of Farm, Forest and Transport Machines, University of Life Sciences in Lublin, \\ e-mail: janusz.zarajczyk@up.lublin.pl, ORCID 0000-0001-5954-6575 \\ * Corresponding author: e-mail: janusz.zarajczyk@up.lublin.pl

\begin{tabular}{|c|c|}
\hline ARTICLE INFO & ABSTRACT \\
\hline $\begin{array}{l}\text { Article history: } \\
\text { Received: March } 2020 \\
\text { Received in the revised form: } \\
\text { April } 2020 \\
\text { Accepted: May } 2020\end{array}$ & \multirow{2}{*}{$\begin{array}{l}\text { Results of laboratory tests on the sowing quality of Vistula parsley } \\
\text { seeds with a working section of a seed drill by Weremczuk company } \\
\text { Max Pneumatic S } 156 \text { model with a pneumatic sowing system were } \\
\text { presented. Tests of the sowing section of a seed drill were carried out in } \\
\text { laboratory conditions on a special stand. They showed that the seed drill } \\
\text { speed and rotations of the sowing disc have a significant impact on the } \\
\text { sowing quality expressed with participation of single, double sowing } \\
\text { and passes. The most favourable results at all set distances between } \\
\text { seeds in a row were obtained with a seed drill speed of } 1 \mathrm{~km} \cdot \mathrm{h}^{-1} \text {. On the } \\
\text { other hand, the increase of the working speed of a seed drill and rota- } \\
\text { tions of a sowing disc influenced significantly the deterioration of the } \\
\text { sowing quality. }\end{array}$} \\
\hline $\begin{array}{l}\text { Key words: } \\
\text { precision sowing quality, } \\
\text { seed drill, } \\
\text { parsley seeds }\end{array}$ & \\
\hline
\end{tabular}

\section{Introduction}

Parsley comes from the Mediterranean region where it is still wild. Its cultivation is popular in the temperate climate. The main producers of parsley are France, the Netherlands and countries of central Europe. In the 90's of the 20th century harvesting of root parsley constituted ca. 3.5-3.85\% of the entire yield of field vegetables (Babik and Dudek, 2000; Błażewicz-Wożniak, 1997; GUS, 2017). Its cultivation acreage was 1300 ha which was ca. $5 \%$ of the general acreage of vegetables (Rumpel and Kaniszewski, 1994; GUS, 2017). The Central Statistical Office information on parsley are summed up as the so-called other vegetables. The cultivation acreage of these vegetables is systematically growing; in 2017 the general area of cultivation was 66.5 thousand ha (GUS, 2017). A further increase of parsley production is economically justified due to the increasing demand for food industry (for dried vegetables, concentrates, etc.). Despite the use of sowing material with a high quality, the amount of the seedlings obtained in the field is low. It concerns mainly parsley (Janas et al., 2013; Dyśko and Kaniszewski 2007; Błażewicz-Wożniak, 1998; Gillham and Dodge, 1987; Gaworski, 1998). Many authors emphasise great requirements of parsley with regard to soil, 
atmospheric conditions, or cultivation treatments, especially during sowing and plants germination. Parsley may be cultivated flatwise or on ridges and similarly as in case of carrot ridges of $20 \mathrm{~cm}$ height with a similar width in the top part. Root parsley seeds germinate long and irregularly. In the optimal temperature of $20-30^{\circ} \mathrm{C}$, the sowing time till the first germinations lasts ca. 10-20 days and in unfavourable conditions it may be extended even to 30-40 days. Thus, seeds should be sown to the depth of 1-2 $\mathrm{m}$. Too deep sowing may cause a delay of germination or failure of seeds to germinate. Seeds sown too deep may be easily washed away from soil. Because of a prolonged germination period of seeds and not using herbicides, they may be sown with the so-called indicator plant which indicates the parsley rows. Per $1 \mathrm{~kg}$ of seeds, one can add: $70 \mathrm{~g}$ of radish, $50 \mathrm{~g}$ of kohlrabi, $30 \mathrm{~g}$ of salad or $50 \mathrm{~g}$ of poppy seed (Janas et al., 2013). In the cultivation on ridges (distributed every $67.5 \mathrm{~cm}$ or $75 \mathrm{~cm}$ ) it is recommended to sow in double rows distributed every $6-8 \mathrm{~cm}$ with maintenance of ca. $2.5 \mathrm{~cm}$ spacing between seeds in rows ( 80 seeds per 1 running metre of the double row). The sowing standard in cultivation for fall harvesting is $1.5-2 \mathrm{~kg}$ or $1-1.5 \mathrm{~kg}$ of seeds per one hectare, respectively for seeds by 80 and 90 percent of germination ability. Parsley is sown densely for bunch harvesting, usually it is $2-4 \mathrm{~kg}$ of seeds per one hectare. The sowing depth is $2 \mathrm{~cm}$ - for heavier soils, $3 \mathrm{~cm}$ - for lighter ones and $4 \mathrm{~cm}$ for peat soils. Horticultural seed drills with sectional construction and a row manner of seed sowing, equipped with seed wheels and press seed drill (Bracy and Parish, 1998; Markowski, 2017) have been used so far in Poland. These seed drills enable sowing of the amount of seeds that is required per an area unit, with maintenance of the set width of interrows; however, they, do not ensure a regular distribution in rows and uniform depth of sowing. When using those less precise barrow press seed drills one may increase the precision of sowing by mixing parsley seeds with a balast in the form of dead seeds (killed with a high temperature) of carrot or parsley. A precise sowing of the recommended amount of parsley seeds requires the use of precision seed drills- pneumatic or mechanical ones (Łazarczyk et. al., 1996; Özmerzi et. al., 2002; Ozturk et. al. 2006; Çakir et. al., 2016). We could have noticed such attempts of using a precise sowing with regard to the plant cultivars which were previously sown not with a precise method (Griepentrag, 1996; Pecio, 1996; Ruszkowski and Filipiak, 1990; Lisowski, 2006). When precise seed drills for sowing seeds of various sizes and shapes, including fine seeds) appeared in Poland (like the one produced by Weremczuk company in Lublin Max Pneumatic S 156) caused development of the precise sowing technique. The problem of the precise sowing has a particular meaning when referred to fine seeds such as parsley (Banasiak and Michalak, 2000; Podleśny, 2006; Markowski et al., 2012).

The objective of the research was assessment of the sowing quality (lengthwise regularity) of Vistula radish seeds with the sowing unit of Max Pneumatic S 156 with a pneumatic seeder.

\section{Materials and Methods}

The object of studies was Max Pneumatic S 156 seed drill by Weremczuk company, which may sow such seeds as: parsley, onion, etc. 
Assessment of selected...

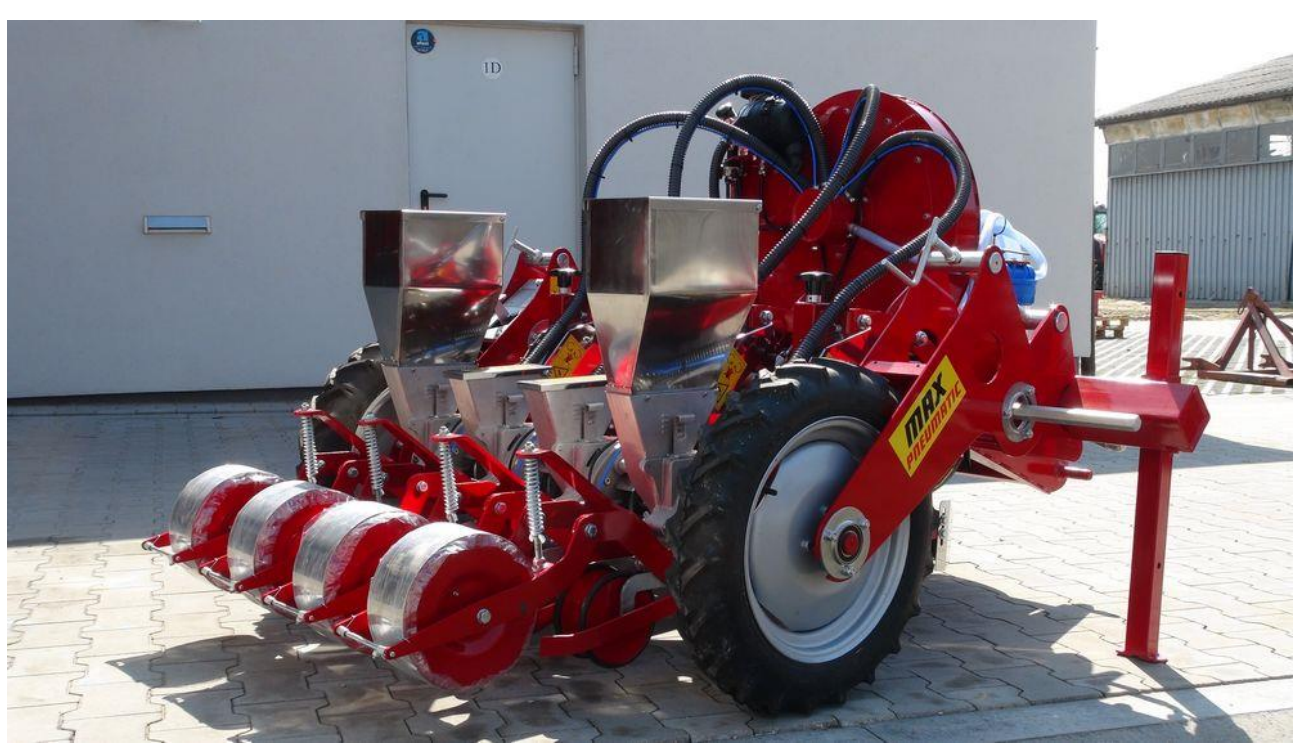

Figure 1. Vegetable seed drill, pneumatic 4-sectional MAX PNEUMATIC (www.weremczukagro.pl)

Max Pneumatic S 156 (Fig. 1) has a bearing beam of the width of 2.0-3.0 m (depending on the number of sections). The structure is suspended on a three-point suspension system of a tractor, a bearing beam enables placing of 8 sowing sections. A shielded fan air compressor and belt transmission, which serve for driving of these units are mounted on a frame. Collectors are located on the fan shield, the first of negative pressure - which sucks seeds to a disc, the second of negative pressure - for mixing seeds. A central drive of a sowing disc comes from front support and drive wheels, back wheels serve for pressing the surface layer of soil. Each section has a separate tank for sowable material with the capacity of 1.71 with a swage 12.81 .

The seed drill enables a very wide range of settings, it has 6 ratios, its minimal row distribution is $23 \mathrm{~cm}$ while the distance of seed sowing is determined in a row from $1.2 \mathrm{~cm}$ to $79.8 \mathrm{~cm}$. The size of sown seeds is at the level of $0.8 \mathrm{~mm}$ to $10 \mathrm{~mm}$ depending on the disc. The body of the sowing unit, shield and tank are made of aluminium castings (Fig. 2).

The tests were carried out on a special stand (Fig. 3) in the University of Life Sciences in Lublin in laboratory conditions. One of the main elements of the test stand is an adhesive belt. It bears a linear scale which enables measurement of the distance between the sown seeds. The belt is spread between two belt wheels and driven by an electric engine. Engine rotations are controlled with a frequency converter. A working section of the investigated seeder is mounted directly over the belt. The sowing section is driven by an electric engine and its peripheral speed changes with a frequency transducer. Such solution of the drive enabled independent and gradeless regulation of the belt speed and rotations of the sowing disc. 


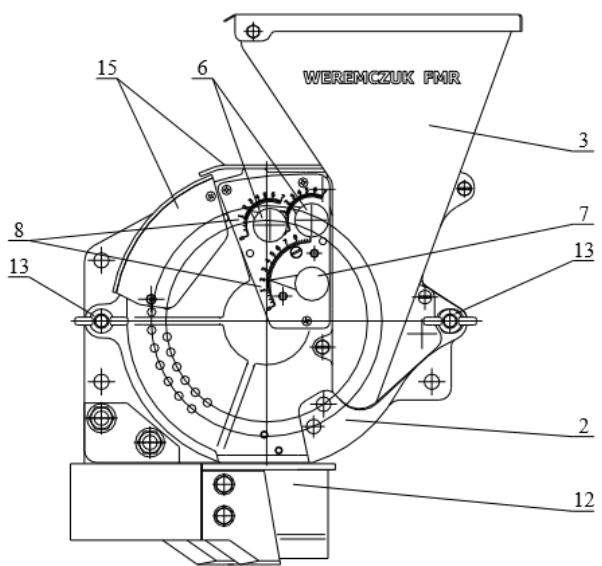

a)

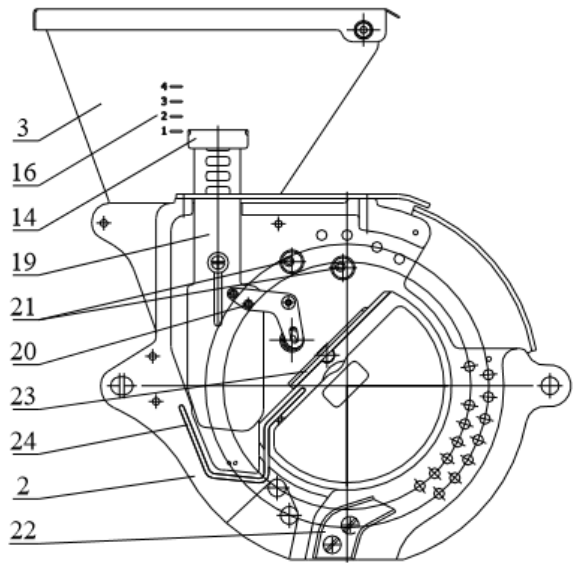

c)

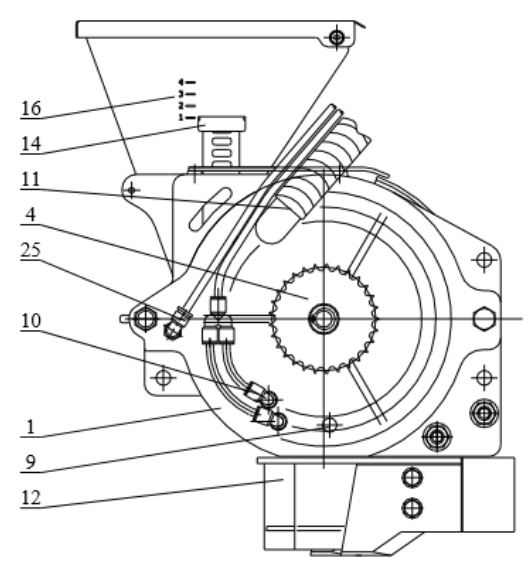

b)

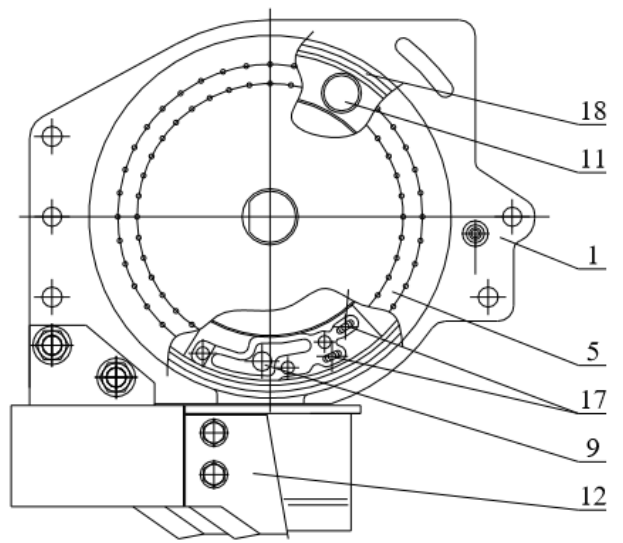

d)

Figure 2. Seed drill view, $a$ and b) projection of a cover from the inside, $c$ and d) projection of the body from the inside: 1 - seed drill body, 2 - seed drill cover, 3 - seed hopper, 4 - discs driving chainwheel, 5 - seeding disc, 6 - lower scrapers knobs,7-upper scrapers knobs , 8-scraper setting scales, 9 -seed discharge, 10-disc purging, 11 -suction hose elbow, 12 -coulter, 13 - butterfly nut of the cover mounting, 14 - shutter band, 15 -transparent side and upper shield, 16 - shield height setting scale, 17-purging nozzle, 18 - disc seal, 19 - seed shield, 20-upper scraper, 22 - end scraper, 23 - sealing plate, 24 - chamber seal, 25 - reduction of seed mixing pressure. 


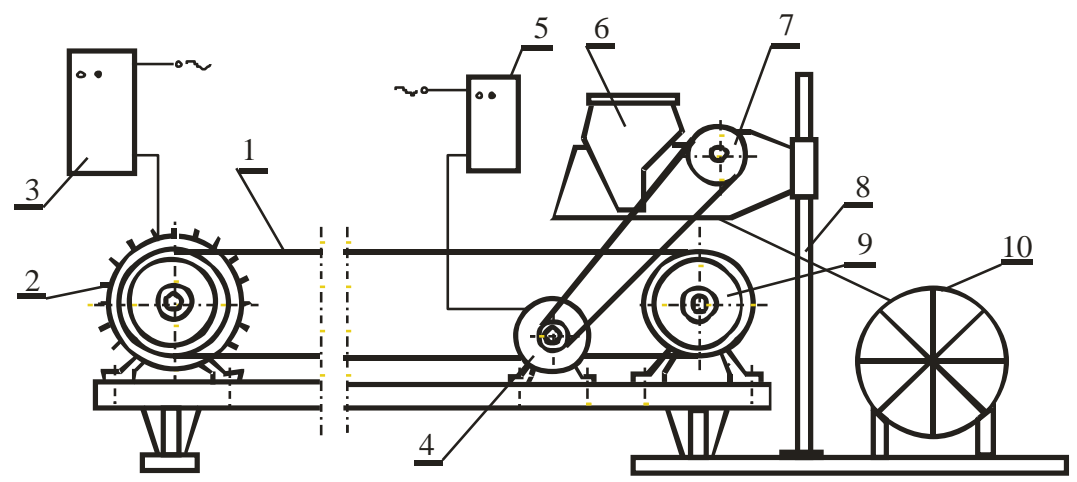

Figure 3. Diagram of the test rigs: 1 -adhesive belt, 2, 4 -electric engine, 3,5-frequency converter, 6 -sowing unit, 7 -drive wheel of the sowing unit, 8 -support, 9 -tension roller of adhesive belt, $10-$ fan

The test stand was used to take measurements concerning the impact of various speeds of the working section of the seed drill and peripheral velocity of the sowing disc on the sowing quality of parsley seeds (Feder et al., 2012). Sowing was performed in two rows with a twochannel coulter.

For sowing Vistula parsley seeds a disc type was selected based on the geometrical dimensions of seeds (table 1), which were determined based on the measurements of 100 randomly selected seeds. Germination ability and 1000 seeds mass was read out from commercial packaging.

Table 1.

Characteristics of sown Vistula parsley seeds

\begin{tabular}{lcc}
\hline Seed property & Unit of measurement & Average \\
\hline Length & $(\mathrm{mm})$ & 2.0 \\
Width & $(\mathrm{mm})$ & 1.1 \\
Thickness & $(\mathrm{mm})$ & 0.6 \\
1000 thousand seeds mass & $(\mathrm{g})$ & 1.1 \\
Germination ability & $(\%)$ & 98.0 \\
\hline
\end{tabular}

The quality assessment of parsley seeds sowing with a working section of Max Pneumatic S 156 was performed based on the methodology included in the norm ISO 7256/1 (Banasiak and Michalak, 2000; Błaszczak and Przybył, 2000; Przybył and Błażczak, 2000; Bozdogan, 2006; Lipiński et al., 2004).

Working parameters of the investigated seed drill (Table 1) were within the range determined by a producer during sowing of parsley seeds and were: the working speed of a seed drill 3.2-6 $\mathrm{km} \cdot \mathrm{h}^{-1}$, distance between the seeds in a row $24-78 \mathrm{~mm}$, maximum rotations of the seeding disc $40 \operatorname{rot} \cdot \mathrm{min}^{-1}$. The studies were performed with lower working speeds of a seed drill within 1-3 $\mathrm{km} \cdot \mathrm{h}^{-1}$ and it was checked whether they significantly influence the seeding quality. These low speeds were selected based on the initial studies. While, quite low speed resulted from the need for analysis of its impact within a low range. 
Szymon Ignaciuk, Janusz Zarajczyk

Table 2.

Working parameters of the laboratory stand with the used seed drill Max Pneumatic S 156

\begin{tabular}{lcc}
\hline $\begin{array}{l}\text { Distance } \\
(\mathrm{mm})\end{array}$ & $\begin{array}{c}\text { Belt speed } \\
\left(\mathrm{km} \cdot \mathrm{h}^{-1}\right)\end{array}$ & $\begin{array}{c}\text { Disc speed } \\
\left(\text { rot. } \cdot \mathrm{min}^{-1}\right)\end{array}$ \\
\hline & 1.0 & 8.34 \\
20 & 3.0 & 16.37 \\
& 4.0 & 25.01 \\
\hline \multirow{3}{*}{30} & 1.0 & 5.56 \\
& 3.0 & 16.67 \\
40 & 4.0 & 22.23 \\
\hline & 1.0 & 4.17 \\
& 3.0 & 12.50 \\
& 4.0 & 16.67 \\
\hline
\end{tabular}

Parsley seeds sown with a seeding section of the seed drill at the set working parameters were falling on the moving adhesive belt which stimulates seed drill motion towards the soil surface. After seeding, spacing between seeds in rows along $1 \mathrm{~m}$ were measured in five iterations. Then, according to the standard ISO 7256/1 participation of single, double seedings and passes were determined. Single sown seeds included those between which the distance was bigger from the half and lower or equal 1.5 of the average real spacing. Double-sown seeds included seeds which were distributed in spacing smaller or equal to the half of the average real spacing. Passes included spacing bigger than 1.5 of average real spacing.

Then, the following was calculated:

- Percentage value of single sowing expressed as a ratio of the number of single-sown seeds to the general number of seeds on the measurement distance.

- The percentage value of double sowings expressed as a ratio of the number of doublesown seeds to the general number of seeds on the measurement distance.

- Percentage value of single sowing expressed as a ratio of the number of passes to the general number of seeds on the measurement distance.

\section{Results and Discussion}

The obtained results of laboratory tests of Vistula parsley seeding with the investigated seed drill was presented in tables and diagrams. Moreover, a statistical analysis was performed.

Table 3 presents the obtained, averaged test results of working parameters of a pneumatic seed drill on the quality of a two-row sowing of Vistula parsley seeds.

Various letters given in indexes mean that at the investigated working speeds of the seeder, statistically significant differences occurred between the percentage participation of single, double sowings and passes at the level of $\alpha=0.05$

The impact of the working speed of the seed drill and a rotating disc on the relation of the set distance to the average obtained distance was presented in table 3. In majority of cases, statistical analysis proved a significant impact of the seeding speed and seeding disc rotations on the seeding quality of Vistula parsley seeds. However, seeds, quite often in the number of 
Assessment of selected...

three were sucked in to one slot and scraper did not catch them. Thus, one may conclude that this problem significantly disturbs the obtained test results.

The following figures: 4,5 and 6 show the test results concerning the seeding quality of Vistula parsley seeds at the set working speeds and set distances between seeds in a row.

Table 3 .

Average results of tests performed on the laboratory stand of Vistula parsley seeds sowing with a pneumatic seed drill Max Pneumatic S 156 in two rows

\begin{tabular}{|c|c|c|c|c|c|c|c|c|c|c|}
\hline \multirow{2}{*}{$\begin{array}{l}\text { Set distance } \\
\text { between } \\
\text { seeds } \\
(\mathrm{mm})\end{array}$} & \multirow{2}{*}{$\begin{array}{l}\text { Working } \\
\text { speed } \\
\left(\mathrm{km} \cdot \mathrm{h}^{-1}\right)\end{array}$} & \multirow{2}{*}{$\begin{array}{l}\text { Rotational } \\
\text { speed } \\
\text { Of sowing } \\
\text { disc } \\
\left(\text { rot. } \cdot \min ^{-1} \text { ) }\right.\end{array}$} & \multicolumn{2}{|c|}{$\begin{array}{c}\text { Average } \\
\text { distances } \\
\text { between } \\
\text { seeds in a row } \\
(\mathrm{mm})\end{array}$} & \multicolumn{2}{|c|}{$\begin{array}{c}\text { Single } \\
\text { sowing } \\
(\%)\end{array}$} & \multicolumn{2}{|c|}{$\begin{array}{c}\text { Double } \\
\text { sowing } \\
(\%)\end{array}$} & \multicolumn{2}{|c|}{$\begin{array}{c}\text { Passes } \\
(\%)\end{array}$} \\
\hline & & & $\begin{array}{l}\text { Right } \\
\text { coul- } \\
\text { ter } \\
\text { chan- } \\
\text { nel }\end{array}$ & $\begin{array}{l}\text { Left } \\
\text { coul- } \\
\text { ter } \\
\text { chan- } \\
\text { nel }\end{array}$ & $\begin{array}{l}\text { Right } \\
\text { coul- } \\
\text { ter } \\
\text { chan- } \\
\text { nel }\end{array}$ & $\begin{array}{l}\text { Left } \\
\text { coul- } \\
\text { ter } \\
\text { chan- } \\
\text { nel }\end{array}$ & $\begin{array}{l}\text { Right } \\
\text { coul- } \\
\text { ter } \\
\text { chan- } \\
\text { nel }\end{array}$ & $\begin{array}{l}\text { Left } \\
\text { coul- } \\
\text { ter } \\
\text { chan- } \\
\text { nel } \\
\end{array}$ & $\begin{array}{l}\text { Right } \\
\text { coul- } \\
\text { ter } \\
\text { chan- } \\
\text { nel } \\
\end{array}$ & $\begin{array}{l}\text { Left } \\
\text { coul- } \\
\text { ter } \\
\text { chan- } \\
\text { nel }\end{array}$ \\
\hline \multirow{3}{*}{20} & 1 & 8.34 & 14 & 12 & $47^{\mathrm{a})}$ & $45^{\mathrm{a})}$ & $32^{\text {a) }}$ & $33^{\text {a) }}$ & $22^{\mathrm{a})}$ & $22^{\mathrm{a})}$ \\
\hline & 3 & 16.37 & 16 & 14 & $39^{b)}$ & $38^{\text {b) }}$ & $39^{\mathrm{b})}$ & $41^{\mathrm{b})}$ & $22^{\mathrm{a})}$ & $24^{\mathrm{a})}$ \\
\hline & 4 & 25.01 & 19 & 16 & $39^{\mathrm{b})}$ & $39^{\text {b) }}$ & $38^{\mathrm{b})}$ & $38^{\text {c) }}$ & $23^{\text {a) }}$ & $23^{\text {a) }}$ \\
\hline \multirow{3}{*}{30} & 1 & 5.56 & 18 & 20 & $43^{\mathrm{c})}$ & $44^{\text {c) }}$ & $34^{\mathrm{c})}$ & $35^{\mathrm{d})}$ & $23^{\text {a) }}$ & $21^{\text {a) }}$ \\
\hline & 3 & 16.67 & 9 & 20 & $42^{\text {c) }}$ & $47^{\text {d) }}$ & $35^{\mathrm{c})}$ & $32^{\mathrm{d})}$ & $23^{\text {a) }}$ & $21^{\text {a) }}$ \\
\hline & 4 & 22.23 & 6 & 18 & $44^{\text {c) }}$ & $44^{\mathrm{e})}$ & $31^{\text {d) }}$ & $32^{\mathrm{d})}$ & $24^{\text {a) }}$ & $24^{\text {b) }}$ \\
\hline \multirow{3}{*}{40} & 1 & 4.17 & 28 & 27 & $35^{\text {d) }}$ & $51^{f)}$ & $40^{\mathrm{e})}$ & $26^{\mathrm{e})}$ & $25^{\mathrm{a})}$ & $23^{\mathrm{ab})}$ \\
\hline & 3 & 12.50 & 28 & 23 & $37^{\text {d) }}$ & $49^{f)}$ & $41^{\mathrm{e})}$ & $28^{\mathrm{e})}$ & $23^{\mathrm{a})}$ & $24^{\text {b) }}$ \\
\hline & 4 & 16.67 & 28 & 26 & $51^{\mathrm{e})}$ & $33^{\mathrm{g})}$ & $27^{\mathrm{f})}$ & $38^{\mathrm{f})}$ & $22^{\mathrm{a})}$ & $26^{c)}$ \\
\hline
\end{tabular}

Set distance between seeds $(20 \mathrm{~mm})$



$\begin{array}{ll}\square \text { Single sowing - right channel } & \text { Double sowing -right channel } \\ \square \text { Passes - right channel } & \square \text { Sigle sowing - left channel } \\ \square \text { Double sowing - left channel } & \text { Passes - left channel }\end{array}$

Figure 4. Impact of working speed of pneumatic speed drill on percentage participation of single, double sowings and passes in spacing of $20 \mathrm{~mm}$ 
The graph presented above (Fig. 4) and taking into consideration also the obtained average distance between the seeds (Table 3) show that the most favourable working speed of a seed drill is: $1 \mathrm{~km} \cdot \mathrm{h}^{-1}$. A percentage participation of single sowings is $47 \%$ of A row - right coulter channel. The increase of the working speed considerably influences the sowing quality of parsley seeds since along with the increase of the speed, we obtained a worse parsley sowing.

The highest percentage participation of single sowing is $41 \%$ of B row - left coulter channel at the working speed of a seed drill $3 \mathrm{~km} \cdot \mathrm{h}^{-1}$.

The lowest percentage participation of passes of $22 \%$ was reported at the working speed of a seed drill of $1 \mathrm{~km} \cdot \mathrm{h}^{-1}$ of A row - right coulter channel.

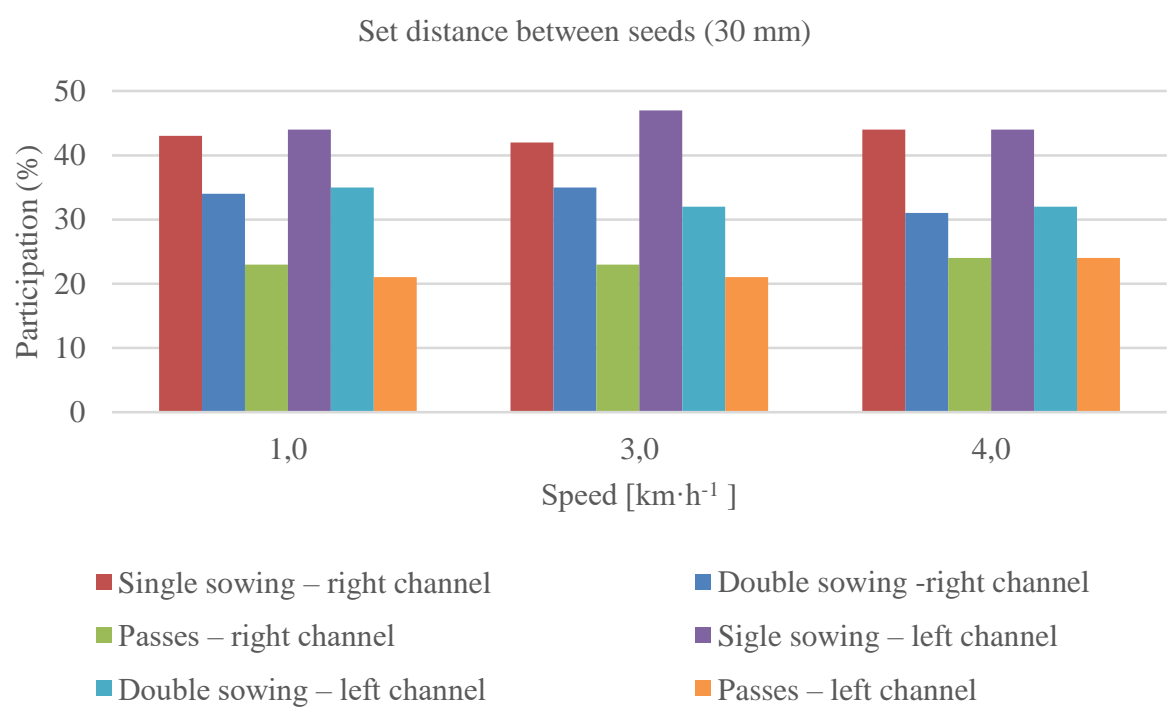

Figure 5. Impact of working speed of pneumatic speed drill on percentage participation of single, double sowings and passes in spacing of $30 \mathrm{~mm}$.

From the above graph (Fig.5) and taking into consideration the obtained average distances between the seeds (Table 3 ) we can see that the most favourable working speed of a seed drill is: $1 \mathrm{~km} \cdot \mathrm{h}^{-1}$. Comparable results concerning single sowings were achieved at the speeds of 3 $\mathrm{km} \cdot \mathrm{h}^{-1}$ and $4 \mathrm{~km} \cdot \mathrm{h}^{-1}$ but at those speeds in one of the channels very small distances between seeds were obtained which influenced the assessment by the authors. A percentage participation of single sowings for the working speed of $1 \mathrm{~km} \cdot \mathrm{h}^{-1}$ is $44 \%$ of B row - left coulter channel.

The highest percentage of double sowing participation is $35 \%$ in the right coulter channel at the working speed of a seed drill of $3 \mathrm{~km} \cdot \mathrm{h}^{-1}$ (probably it is related to a small average distance between seeds). 
Assessment of selected...

The lowest percentage participation of empty sowing of $22 \%$ was reported at the working speed of a seed drill of $1 \mathrm{~km} \cdot \mathrm{h}^{-1}$.

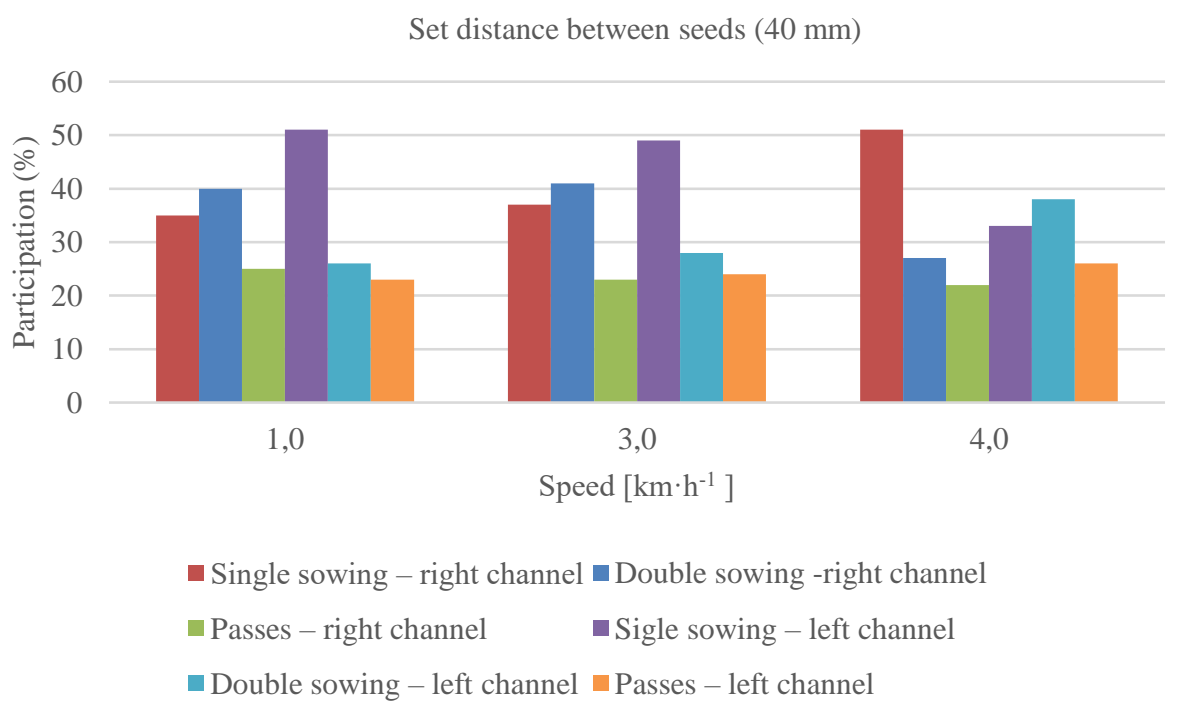

Figure 6. Impact of working speed of pneumatic speed drill on percentage participation of single, double sowings and passes in spacing of $40 \mathrm{~mm}$

The graph presented above (Fig. 6) and taking into consideration the obtained average distances between the seeds (Table 3 ) show that the most favourable working speed of a seed drill is $1 \mathrm{~km} \cdot \mathrm{h}^{-1}$, although the comparable results were obtained also for two remaining working speeds. A percentage participation of single sowings for the working speed of $1 \mathrm{~km} \cdot \mathrm{h}^{-1}$ is $51 \%$ of B row - left coulter channel.

The highest percentage participation of double sowing is $41 \%$ of A row - left coulter channel at the working speed of a seed drill $3 \mathrm{~km} \cdot \mathrm{h}^{-1}$.

The lowest percentage participation of empty sowings of $22 \%$ was reported at the working speed of a seed drill of $4 \mathrm{~km} \cdot \mathrm{h}^{-1}$ of A row - right coulter channel.

\section{Conclusions}

The tests that were performed on the assessment of the impact of the working parameters of a seed drill with a pneumatic sowing system on the sowing quality of Vistula parsley seeds and the statistical analysis of the obtained results enabled to formulate the following conclusions:

1. Based on the initial tests it was stated that along with the increase of the working speeds of a seed drill exceeding $4 \mathrm{~km} \cdot \mathrm{h}^{-1}$ and with the increase of the rotational speed of a disc, sowing of Vistula parsley seeds deteriorated considerably. On the other hand, from among 
three investigated speeds $\left(1 \mathrm{~km} \cdot \mathrm{h}^{-1}, 3 \mathrm{~km} \cdot \mathrm{h}^{-1}\right.$ and $\left.4 \mathrm{~km} \cdot \mathrm{h}^{-1}\right)$ in a general consideration the most favourable sowing was obtained at the speed of $1 \mathrm{~km} \cdot \mathrm{h}^{-1}$.

2. The highest percentage participation of single sowing (within $47 \%$ in A row and $41 \%$ in B row) with regard to the norm ISO 7256/1 was obtained for the distance of $20 \mathrm{~mm}$.

3. The test was carried out at various speeds of a sowing section of a seed drill and various rotational speeds of the seeding disc. It was reported that a small size and irregular shape of parsley seeds negatively influenced the maintenance of a correct average distance between the seeds in a row (Table 3; column 4). It could have also influenced the conclusions.

4. To obtain a full image of the sowing quality we should perform tests for longer measurement distances and possibly other sowing parameters. Such actions limit, inter alia, a statistical impact of diverging observations.

5. The single sowing observed during the test at the level of $33-51 \%$ at the double sowing at the level of $26-41 \%$ (at the working speeds from $1 \mathrm{~km} \cdot \mathrm{h}^{-1} \mathrm{do} 4 \mathrm{~km} \cdot \mathrm{h}^{-1}$ ) resulted from technical reasons. In the branch literature, one may notice a clear trend for summing single and double sowings treating them as the total sowing (Błaszczak and Przybył, 2000). In such a case, the total sowing was within $71-79 \%$ (the sum of participation of single and double sowings for all speeds and both channels), which guarantees a high sowing quality, which translates into reduction of costs at a high yield.

\section{References}

Babik, J., Dudek. J. (2000). New, complex machine for ridge forming, and simultaneous sowing vegetable crops. Vegetable Crops Research Bulletin, 53, 103-110.

Banasiak, J., Michalak, J. (2000). Stanowiskowe badania jakości siewu punktowego nasion. Problemy Inżynierii Rolniczej, 4(30), 21-28.

Błaszczak, P., Przybył, J. (2000). Zastosowanie arkusza kalkulacyjnego Excel do oceny parametrów siewu punktowego. Inżynieria Rolnicza, 3(14), 29-40.

Błażewicz-Wożniak, M. (1997). Wpływ czynników agrotechnicznych na wschody, wzrost i plonowanie pietruszki korzeniowej, uprawianej na glebie zlewnej o nietrwałej strukturze. Cz. I. Wschody roślin. Annales Universitatis Mariae Curie-Skłodowska, sectio EEE, 5, 117-127.

Błażewicz-Wożniak, M. (1998). Wpływ czynników agrotechnicznych na wschody, wzrost i plonowanie pietruszki korzeniowej, uprawianej na glebie zlewnej o nietrwałej strukturze. Cz. III. Plon korzeni i jego struktura. Annales Universitatis Mariae Curie-Skłodowska, sectio EEE, 6, 73-87.

Bozdogan, A.M. (2006). Uniformity of within-row distance in precision seeders: laboratory experiment. Journal of Applied Sciences, 6(10), 2281-2286.

Bracy, R.P., Parish, R.L. (1998). Seeding uniformity of precision seeders. HortTechnology, 8, 182-185.

Çakir, E., Aygün, I., Yazgi, A., Karabulut, Y. (2016). Determination of in-row seed distribution uniformity using image processing. Turkish Journal of Agriculture and Forestry, 40, 874-881.

Dyśko, J., Kaniszewski, S. (2007). Effect of drip irrigation, N- fertigation and cultivation methods on the yield and quality of carrot. Vegetable Crops Research Bulletin, 67, 25-33.

Feder, S., Kęska, W., Kośmicki, Z., Selech, J., Włodarczyk, K., Gierz, Ł. (2012). Laboratoryjne stanowisko do badania procesów wysiewu nasion. Journal of Research and Applications in Agricultural Engineering, 57(1), 34-36.

Gaworski, M. 1998. Seeders for vegetables - precision and modernity. Fruit, vegetables, flowers, 1718(27), 27-28.

Gillham, D.J., Dodge, A.D. (1987). Chloroplast superoxide and hydrogen peroxide scavenging systems from pea leaves: Seasonal variations. Plant Science, 2(50), 105-109. 
Assessment of selected...

Griepentrag, H.W. (1996). Standflachenverteilung und Ertrag von Raps. Landtechnik, 51, 258-259.

GUS (2017). Wyniki produkcji roślinnej w 2017. [cited 4 May 2020]. Available from: https://stat.gov.pl.

International standard ISO 7256/1-1884 (E). 1984. Sowing equipment - test methods Part 1: Single seed drills.

Janas, R., Górnik, K., Grzesik, M. (2013). Instrukcja uprawy pietruszki korzeniowej (Petroselinum crispum Mill.) na nasiona metodami ekologicznymi. [cited 4 May 2020]. Available from: http://www.inhort.pl/files/program_wieloletni/wykaz_publikacji/obszar4/4.3_2013_2_Instrukcja_pietruszka.pdf

Łazarczyk, A., Lipiński, A., Rawa, T. (1996). Próba zastosowania techniki komputerowej w badaniach równomierności dozowania nasion zbóż kołeczkowym zespołem wysiewającym. Roczniki Akademii Rolniczej w Poznaniu, CCLXXXVI, Rolnictwo, 49, 121-129.

Lipiński, A., Markowski, P., Rawa, T. (2004). Próba oceny wydajności i równomierności dozowania nasion pszenicy kołeczkowymi zespołami wysiewającymi przy wysiewie dolnym i górnym. Inżynieria Rolnicza, 4(59), 69-76.

Lisowski A. (2006). Siewnik mechaniczny czy pneumatyczny? Hasło Ogrodnicze. [cited 4 May 2020] Available from: https://www.ho.haslo.pl/article.php?id=2947\&rok=2006\&numer=09.

Markowski, P. (2017). Technical and technological parameters of performance evaluation of multipurpose and special single-seed drills based on seeding uniformity. Wydawnictwo Uniwersytetu-Warmińsko w Olsztynie, 148. ISBN 978-83-8100-093-2.

Markowski, P., Cejman, K., Rawa, T., Kaliniewicz, Z., Lipiński, A. (2012). Wpływ gęstości i prędkości siewu na rozmieszczenie nasion kukurydzy wysiewanych pneumatycznym siewnikiem precyzyjnym. Agricultural Engineering, 4(139), 235-245.

Özmerzi, A., Karayel, D., Topakci, M. (2002). PM-Power Machinery: Effect of sowing depth on precision seeder uniformity. Biosystems Engineering, 82(2), 227-230.

Ozturk, A., Caglar, O., Bulut, S. (2006). Growth and yield response of facultative wheat to winter sowing, freezing sowing and spring sowing at different seeding rates. Journal of Agronomy and Crop Science, 192, 10-16.

Pecio, A. (1996.) Morfologiczny model rośliny i łanu gryki oraz jej plonowanie w zależności od rozmieszczenia roślin na jednostce powierzchni. Instytut Uprawy, Nawożenia i Gleboznawstwa w Putawach. Seria R, 341, 63-79.

Podleśny, J. (2006). Przydatność siewu punktowego w uprawie wybranych gatunków roślin strączkowych. Inżynieria Rolnicza, 10, 13(88), 385-39.

Przybył, J., Błażczak, P. (2000). Assessment of work quality of precision seeders (in Polish). Materials from Jubilee International Scientific Conference at 30th Anniversary of Agricultural Technology Faculty at the Agricultural University in Lublin entitled: "Current problems encountered in agricultural engineering in the light of Poland's EU accession", Issued by Agricultural University in Lublin, Lublin 13-14 September, 154-155.

Rumpel, J., Kaniszewski, S. (1994): Influence of nitrogen fertilization on yield and nitrate nitrogen content of turnip-rooted parsley. Acta Horticulturae, 371, 413-420.

Ruszkowski, M., Filipiak, K. (1990). Wpływ rozmieszczenia roślin na jednostce powierzchni na zmiany produktywności odmian pszenicy ozimej. Fragmenta Agronomica, 1, 56-70. 


\title{
OCENA WYBRANYCH PARAMETRÓW DOTYCZĄCYCH JAKOŚCI SIEWU NASION PIETRUSZKI ODMIANY VISTULA SIEWNIKIEM PRECYZYJNYM Z PNEUMATYCZNYM SYSTEMEM WYSIEWU
}

\begin{abstract}
Streszczenie. Przedstawiono wyniki badań laboratoryjnych dotyczących jakości siewu nasion pietruszki odmiany Vistula sekcją roboczą siewnika firmy Weremczuk model Max Pneumatic S 156 z pneumatycznym systemem wysiewu. Badania sekcji wysiewającej siewnika przeprowadzono w warunkach laboratoryjnych na specjalnym stanowisku. Wykazały one, że prędkość siewnika oraz obroty tarczy wysiewającej mają istotny wpływ na jakość siewu wyrażającą się udziałem wysiewów pojedynczych, podwójnych i przepustów. Najkorzystniejsze wyniki przy wszystkich zadanych odległościach między nasionami w rzędzie uzyskano przy prędkości siewnika wynoszącej $1 \mathrm{~km} \cdot \mathrm{h}^{-1}$. Natomiast wzrost prędkości roboczej siewnika i obrotów tarczy wysiewającej wpływał istotnie na pogorszenie jakości siewu.
\end{abstract}

Słowa kluczowe: jakość siewu punktowego, siewnik, nasiona pietruszki 